\title{
KREDITO RIZIKOS VALDYMO İMONĖSE PROBLEMOS IR JŲ SPRENDIMO BŪDAI
}

\author{
Meilè Jasiené ${ }^{1}$, Antanas Laurinavičius² \\ Vilniaus universitetas, Sauletekio al. 9, LT-10222 Vilnius, Lietuva \\ El.paštas: ${ }^{1}$ jasiene@takas.lt, ${ }^{2}$ antanaslaur@gmail.com
}

Iteikta 2008-05-15; priimta 2008-11-20

\begin{abstract}
Santrauka. Kredito rizikos valdymas nefinansinio verslo įmonėse Lietuvoje yra nauja ir menkai tyrinèta tema, ją nagrinejjančių mokslinių ir analitinių straipsnių yra nedaug. Daugiausia dėmesio, kalbant apie kredito riziką, tenka bankams, o nefinansinio verslo įmonès paliekamos nuošaly. Šių įmonių kredito rizikos analizė reikšmingai papildytų ir praturtintų kredito rizikos valdymo teoriją ir praktiką, kurios šiuo metu daugiausia sukoncentruotos į bankinès rizikos valdymą. Efektyvesnis kredito rizikos valdymas leistų sumažinti dèl pirkejų nemokumo atsirandančius finansinius nuostolius, o kartu ir įmonès bankroto tikimybę. Straipsnyje tyrinėjamos kredito rizikos valdymo nefinansinio verslo įmonèse problemos ir galimi būdai šią riziką mažinti. Tyrimo tikslas - nustatyti kredito riziką didinančius ir mažinančius veiksnius, riziką mažinančias priemones, įvertinti jų efektyvumą; uždaviniai: apibrèžti nefinansinio verslo įmonių kredito rizikos ir jos valdymo problematiką; atlikti kredito rizikos valdymo problemų tyrimą; remiantis gautais rezultatais identifikuoti mažesnei rizikos grupei priskiriamas įmones, kurios galètų būti pavyzdžiu kitoms; pateikti rekomendacijų, kaip užtikrinti veiksmingesnį rizikos valdymą; tyrimo objektas - Lietuvos statybinių medžiagų prekybos ịmonès. Straipsnyje suformuluotos išvados ir pasiūlymai galètų būti naudingi ir panašią veiklą plètojančioms įmonèms.
\end{abstract}

Reikšminiai žodžiai: tiekejjo kreditas, kredito rizika, atsiskaitymų vėlavimai, mokejjimo atidejimo terminas, nuostolis.

\section{PROBLEMS OF CREDIT RISK MANAGEMENT IN COMPANIES AND MEANS OF THEIR SOLUTION}

\author{
Meilè Jasiené ${ }^{1}$, Antanas Laurinavičius ${ }^{2}$ \\ Vilnius University, Sauletekio al. 9, LT-10222 Vilnius, Lithuania \\ E-mails: ${ }^{1}$ jasiene@takas.lt, ${ }^{2}$ antanaslaur@gmail.com
}

Received 15 May 2008; accepted 20 November 2008

\begin{abstract}
The paper analyses credit risk management problems in non-financial companies and possible methods for reducing the risk. The research aims at determining the factors influencing the credit risk, establishes the measures reducing the risk and evaluates their effectiveness. A supplier credit is the principal short-term financing source of small and medium-size companies given the insufficient credibility and collaterals of these companies in order to obtain a credit in financial markets. Meanwhile, supplier credit means that suppliers not only finance their customers providing them with cheap resources, but also assume all the credit risk related to financing. In order to find out the ways companies assess this risk, what measures they use to manage it and the effectiveness of these measures, we carried out a research on credit risk management in building materials trading companies in Lithuania. In the course of the research, two major problems the companies confront with were identified, namely the delay of payments and losses related to so-called "bad debts". Delays
\end{abstract}


of payments may be related to limited capacities of credit managers to ensure timely recovery of debts. Long delays may also be determined by longer payment terms. This conclusion denies the attitude prevalent in practice that upon giving longer payment terms for customers, they will reduce their delays. In fact, when solving the problem of delays the companies should act in the opposite way and shorten payment terms, or deal with this problem in other ways, for example, by choosing certain measures of settlement management. Delays, in turn, directly influence the magnitude of losses related to bad debts. Therefore, in order to minimize the losses, it is necessary first of all to reduce the delays of payments. And the measures of credit risk management - as the results of the conducted research indicate - help to deal with both payment delays and losses related to bad debts. The best way to minimize delays is the use of credit insurance, suretyship and factoring because those measures involve third party into the settlement process. Thus, the „settlement discipline“, when the debtor knows that the creditor, having not received the payment in due time, may apply for the settlement to the third party, namely to the insurer, surety or factor, is created. The results of the research on credit risk management in Lithuanian building materials trading companies allow to identify the companies attributed to the lower risk group that could be held as an example to other companies and produce recommendations how to ensure a more effective risk management.

Keywords: supplier credit, credit risk, delays of payments, payment term, loss.

„Jei neprisiimtume jokios rizikos, negalètume uždirbti pinigų, nes rizika yra ir galimybé

Otto Steinmetz,

„Dresdner Bank“ vyriausiasis rizikos valdytojas

\section{1. İvadas}

Yra skiriamos dvi kredito formos - piniginis ir prekinis kreditas. Pagrindine piniginio kredito rūšis - banko kreditas. Prekinis kreditas dar vadinamas pardavèjo arba tiekèjo kreditu ${ }^{1}$. Tiekejo kreditas yra svarbiausias trumpalaikis imonių finansavimo šaltinis, savo apimtimi viršijantis net tokius bankų produktus, kaip kredito linija ar indèlio pereikvojimas. Tiekejjų kreditai ypač svarbūs mažoms ir vidutinèms įmonèms, kurių veiklos patikimumo ir garantijų nepakanka norint gauti kreditą finansų rinkoje - tiekejjo kreditas yra patrauklus įmonèms dèl nesudètingų gavimo procedūrų. Didelès įmonès dažniausiai naudoja šiuos kreditus tuo atveju, kai jų veikla susijusi su užsienio šaliu i̇monėmis (importo ir eksporto operacijos). Kalbant apie tiekëjų kreditų rizikingumą pasakytina, kad šie kreditai daug rizikingesni už bankinius, nes beveik visada suteikiami be jokio užstato ar kitokių i̇vykdymo užtikrinimo priemonių ir labai dažnai neatlygintinai ${ }^{2}$. Tad kodèl jie iš viso egzistuoja?

Delannay ir Dietsch (1999) teigia, kad tiekejo kreditas yra tarsi banko kredito pakaitalas. Jo svarba (ypač mažų ir vidutinių įmonių trumpalaikiam finansavimuisi) išauga recesijos laikotarpiais, o banko kreditų tuo pačiu metu sumažèja. Pasak Bardes (2000), tiekẻjo kredito trukmè (arba mokejjimo atidejjimo terminai) taip pat svyruoja priklausomai nuo ekonomikos ciklo: ilgèja ekonominiam augimui lètejant ir sutrumpejja ekonomikos pakilimo metu. Iš tiesų egzistuoja kelios priežastys, kurios galètų paaiškinti tiekèjo kredito egzistavimą:

1. Šis kreditas nèra tik išorinio finansavimosi šaltinis. Nadiri (1969) tiekèjo kreditą, kaip ir prekių kainą, vertina

1 Toliau tekste vartojamas šis terminas.

2 Tiekejo kreditą galima laikyti neatlygintinu, jei prekių tiekimo sutartyje nèra numatytos nuolaidos atsiskaitant anksčiau sutarto termino. kaip vieną svarbiausių pardavimo politikos priemonių, leidžiančių pritraukti naujų klientų.

2. Ferris (1981) teigia, kad tiekejo kreditas leidžia sumažinti sandorio sąnaudas, jei perkama dažnai (nereikia atsiskaitinèti kiekvieną kartą).

3. Brennan et al. (1988) mano, kad tiekejo kreditas egzistuoja, nes suteikia galimybę diskriminuoti kainomis. Dèl teisinių ar ekonominių priežasčiu gali būti neleidžiama ar tiesiog nenaudinga diskriminuoti kainomis, tačiau tiekejo kreditas ir suteikiamos nuolaidos už atsiskaitymą anksčiau numatyto termino leidžia tai daryti. Be to, šis būdas nepastebimas tiems pirkëjams, kurių jis neliečia.

4. Boissay (2004) teigia, kad tiekèjo kreditas egzistuoja dèl informacijos asimetrijos tarp įmonių, viena vertus, ir jų tiekejjų bei bankų, kita vertus. Bègant laikui, tiekejjai igyja daugiau informacijos apie savo klientus nei bankai, be to, jie geriau išmano ir apie rinką, kurioje dirba. Tokiu būdu tiekejjo kreditas kyla kaip banko kredito alternatyva, ypač kai jị bankai atsisako suteikti dèl išteklių ribotumo (credit rationing).

Tiekejo kreditas Lietuvoje vis dar labai dažnai neatlygintinas (nemokamas), todèl kaip finansavimosi forma jis labai patrauklus įmonèms pirkèjoms. Tad tiekèjai ne tik kredituoja savo pirkejus, aprūpindami juos pigiais ištekliais, bet ir kartu prisiima visą kredito riziką. Šią riziką didina ir tai, kad dažniausiai tiekejo kreditas suteikiamas be jokio užstato ar kitu îvykdymo užtikrinimo priemonių, kliaujantis vien tik ilgamete bendradarbiavimo patirtimi, o tai, kaip rodo atlikto tyrimo rezultatai, ne visada padeda išvengti rizikos ir su ja susijusių nuostolių.

Todel, kaip patvirtina „Intrum Justitia“ atliktas tyrimas (Intrum Justitia 2006), beveik $13 \%$ įmonių yra rimtai susirūpinusios dèl savo egzistavimo ateityje - ir tai spartaus ekonominio augimo sąlygomis! Pagrindinè tokio susirūpinimo priežastis - klientų nemokumas ir sunkiai valdoma kredito rizika. 
Neaiškios ekonomikos perspektyvos, didejjanti įtampa finansų rinkose, kuri jau kelia grèsmę ekonomikai, o ypač tiems jos sektoriams, kurie labai priklausomi nuo bankų kreditavimo, pvz., statybų verslui, verčia susitelkti ị rizikos valdymą, neužmirštant, kad rizika - neatsiejama verslo dalis.

Straipsnyje išdèstytos teorinès tyrimo prielaidos, pateikiamos tyrimo metu identifikuotos problemos (atsiskaitymų vèlavimas ir nuostoliai dèl pirkejų nemokumo), siūlomi šių problemų sprendimo būdai ir rekomendacijos.

\section{Kredito rizika, jos priežastys ir valdymo priemonès}

Verslas neatsiejamas nuo rizikos, o viena iš skaudžiausiai verslą veikiančių rizikos rūšių yra kredito rizika. Tokios rizikos objektas - tiekejjo kreditas. Tai kreditas, kuri pirkejjui suteikia prekių ar paslaugų pardavejas, atidèdamas mokejjimo terminą. Kredituojant tiesiogiai, tiekèjas pateikia prekes pirkejjui be tarpininko (bankui ar kitai kredito institucijai) ir laukia apmokèjimo. Nuo banko kredito jis skiriasi tuo, kad dažniausiai suteikiamas neatlygintinai, todèl dažnai vadinamas pigiausiu įmonių finansavimosi šaltiniu.

Esant netiesioginiam kreditavimui (faktoringui ar forfeitingui) kreditą suteikia bankai ar kitos kredito institucijos, išpirkdami atsiskaitymų dokumentus. Nuo įprasto piniginio kredito, kurị suteikia bankai ar kitos finansų institucijos, ši kredito forma skiriasi tuo, kad būna tik trumpalaikè (dažniausiai iki 3 mèn.), o gavèjai - įmonès.

Kredito rizika atsiranda visais atvejais, kai verslo proceso metu viena iš šalių pristato prekes, suteikia paslaugas ar atlieka darbus prieš gaudama už tai atlyginimą iš kitos sandorio šalies, t. y. atlieka šalių susitarimu numatytą savo įsipareigojimų dali mainais už kitos sandorio šalies ịsipareigojimą atlikti savają prievolès dalį ateityje. Kredito rizika reiškia, kad, pasibaigus sutartam atsiskaitymų už pirktas prekes (ar suteiktas paslaugas) laikotarpiui, debitorius (pirkèjas, skolininkas) gali būti finansiškai nepajègus atsiskaityti su kreditoriumi (pardaveju) arba tiesiog gali vengti sutartyje numatyto atsiskaitymo. UAB "Creditcollect" specialistų vertinimu, kasmet Lietuvos įmonès dèl kredito rizikos patiria iki $1 \mathrm{mlrd}$. Lt nuostolių.

Kaip jau minèta, svarbiausia kredito rizikos atsiradimo imoneje sąlyga - prekinis kreditas, suteikiamas pirkejjui. Akivaizdu, kad tokiu atveju visuomet kyla rizika, kad pirkejjas nustatytu laiku su pardavèju neatsiskaitys (arba neatsiskaitys iš viso), nes per minètą laikotarpi galèjo pablogèti finansine pirkèjo būklè. Be to, toks atsiskaitymo būdas pritraukia ir tokius pirkejjus, kurie reikalingų lěšų iš viso neturi ir mokèti net neplanuoja (apgavystès, sukčiavimo atvejai). Taigi kredito rizikos priežastis sąlygiškai galima suskirstyti i tyčines ir objektyvias (netyčines). Abiem atvejais daug itakos turi informacijos asimetrija tarp pirkèjo ir pardavèjo. Tačiau ši asimetrija ypač didelè tyčinès kredito rizikos atveju. Ir vis dellto egzistuoja tam tikros prielaidos ${ }^{3}$ apie

\footnotetext{
3 Prielaidos suformuluotos remiantis praktine patirtimi; jų reikšmingumas tikrintas tyrimo metu.
}

pirkèjų, siekiančiu pasipelnyti apgavysčiu būdu, elgseną. Šiuo atžvilgiu rizikingiausiomis laikomos naujos įmonès ir imonès, turinčios naujus savininkus ar naujus vadovus.

Toks samprotavimas pagristas prielaida, kad ilgai, stabiliai dirbanti įmonè neturètų būti sužlugdyta dèl vienkartinès apgavystės. Dažniausiai siekiant nesąžiningai pasipelnyti, ikuriamos „vienkartinès“ i̇monès; kita vertus, tam gali būti panaudotos ir ịmonès, susidūrusios su didelèmis finansinemis problemomis. Jomis gali susidometi ir jas pigiai nusipirkti asmenys, turintys nesąžiningų ketinimų. Tačiau tokiu atveju padidintą įmonès riziką atskleis jos savininkų kaita. Galiausiai beveik visada tokie atvejai susiję ir su vadovu pasikeitimu.

Padidintą naujų i̇monių riziką rodo ir tai, kad joms draudimo apsaugos (kredito limitų) nesuteikia ir kreditu draudimo bendrovès ${ }^{4}$. Dažniausiai motyvuojama tuo, kad nežinoma tokių i̇monių atsiskaitymo patirtis.

Kita rizikingų įmonių grupe - smulkesnès pagal turtą, pajamas ir darbuotojų skaičių įmonès. Be to, kuo toliau, tuo labiau ši tendencija tampa ryškesnė: vidutinis bankrutuojančių ir bankrutavusių ịmonių turtas bankroto proceso pradžioje 1993-2004 m. buvo lygus 1,3 mln. Lt, o vien 2004 $\mathrm{m}$. jis sieke jau tik $0,5 \mathrm{mln}$. Lt; darbuotojų vidutiniškai buvo atitinkamai 20 ir 6.

Vertinant įmones pagal verslo organizavimo formą, su didžiausia rizika taip pat susiduria mažiausieji rinkos dalyviai - individualios įmonès. Jos sudare ketvirtadali $2005 \mathrm{~m}$. pirmą pusmetį bankrutavusių i̇monių ir 13,3\% visų 1993-2005 m. bankrutavusių i̇monių. Vertinant pagal veiklos rūšis, didžiausią dalị (42\%) visų bankrutavusių imonių sudaro prekybos įmonès.

Kita jau minèta, kredito rizikos priežastis - informacijos asimetrija tarp pirkèjo ir pardavejo: pirkèjas geriau žino savo riziką, tačiau šia informacija jis nelinkęs pasidalinti su pardavèju. Tad tiekèjams perkeliama neproporcingai didelè finansinè rizika dèl informacijos trūkumo.

Gali kilti klausimas - kodèl tiekejjai neatsisako mokejjimo atidejimo terminų, jei susiduria su tokia didele rizika. Pagrindinès tiekejjų kredito egzistavimo priežastys jau buvo išvardintos ịvade, lieka tik paminèti, kad toks atsiskaitymo būdas leidžia pirkejjams apmokèti prekes po to, kai jie jau būna jas pardavę mažmeninejje rinkoje. Be to, daug įtakos turi ir konkurencija tarp tiekejjų: Ł̇monès ịsipareigoja ne tik tiekti kokybiškas prekes (ar paslaugas), bet ir suteikti palankias mokejjimo sąlygas - mokèjimo terminus. Kaip tik todèl didmeninè prekyba neịsivaizduojama be tiekejų kreditų ir mokejjimo atidèjimo terminų ${ }^{5}$ (Gronskas 1997).

Kredito rizikos pasekmès susijusios su nuostoliais. Be to, galimos likvidumo problemos ir dèl to ilgejjantys atsis-

\footnotetext{
4 Draudimo limitai nesuteikiami naujai įsteigtoms įmonèms, veikiančioms mažiau nei vienerius metus.

5 UADBB „Balto Link“ 2006 m. atlikti tyrimai rodo, kad Lietuvos įmonès apie $70 \%$ pardavimo apimties vykdo suteikdamos savo klientams mokejjimo atidejimą.
} 
kaitymų terminai su verslo partneriais: tiekejais, bankais ${ }^{6}$. Blogiausiu atveju įmonei net gali grèsti nemokumas, kuris dažnai baigiasi bankrotu. Taigi matyti, kad kredito rizika glaudžiai susijusi su kitomis rizikos rūšimis: finansinių nuostolių, likvidumo, bankroto. Netinkamai valdoma ji gali lemti jų atsiradimą.

Kredito rizikos valdymas - tai priemonès, kurios taikomos siekiant riboti kredito riziką. Šiam tikslui galima pasitelkti ịvairias kredito rizikos mažinimo priemones. Vienos iš jų gali būti naudojamos savarankiškai, o kitos, kredito riziką mažinančios netiesiogiai, naudojamos tik kartu su pirmosiomis. Jų pasirinkimas ir naudojimas priklauso nuo daugelio veiksnių: veiklos sektoriaus, pardavejo ir pirkejjo konkurencinès pozicijos, kainos ir pan. Paminèsime priemones, kurios taikomos ar galètų būti taikomos statybų sektoriuje Lietuvoje (įskaitant ir įmones, kurių veikla prekyba statybinèmis medžiagomis).

Netiesiogiai kredito riziką mažinančios priemonès gali būti šios: atsiskaitymas grynaisiais pinigais mokant iš karto, išankstinis prekių apmokèjimas, ${ }^{7}$ avansinis mokèjimas ${ }^{8}$, akredityvai, čekiai, vekseliai, dokumentu inkasavimas, skolu išieškojimas, skolų apmokejjimas prekèmis ir paslaugomis, vidiniai kredito limitai, bankroto skolininkui paskelbimas, skolininko restruktūrizavimas.

Savarankiškai naudojamos kredito rizikos mažinimo priemonès - tai teisès normų numatytos teisinès priemonès, skirtos valdyti ar sumažinti neigiamus kredito rizikos padarinius: hipoteka, ikeitimas, garantija, laidavimas, kreditų draudimas, faktoringas, forfeitingas.

\section{Problemų nustatymas: atsiskaitymų vẻlavimas ir nuostoliai dèl pirkẻjų nemokumo}

\subsection{Tyrimo organizavimas}

Tyrimas, kurio metu buvo siekta ịvertinti kredito riziką Lietuvos statybinių medžiagų prekybos įmonèse, buvo organizuotas dviem etapais: atliktas bandomasis tyrimas, kuris padejjo išsiaiškinti pagrindinius anketos ir apklausos organizavimo trūkumus, ir pagrindinis tyrimas. Duomenys buvo surinkti anketinès apklausos būdu elektroniniu paštu ir taip pat patikslinti telefoninių pokalbių metu (buvo bendrauta su visomis įmonemis).

Anketa buvo išsiųsta statybinèmis medžiagomis prekiaujančioms įmonèms: Lietuvos statybinių medžiagų prekybos imonių asociacijos narems ir atsitiktinai atrinktoms imonèms, nepriklausančioms asociacijai. Priklausymo ar nepriklausymo asociacijai poveikio tyrimo rezultatams neužfiksuota, išskyrus neasocijuotų įmonių nenorą dalyvauti apklausoje. Visos tyrime dalyvavusios ịmonès priklauso

\footnotetext{
6 Kaip rodo mūsų atliktas tyrimas, egzistuoja ir priešingas ryšys, kai ilgesni atsiskaitymų terminai sukelia nuostolių dẻl pirkèjų nemokumo.

7 Tiek atsiskaitymas grynaisiais pinigais, tiek ir išankstinis prekių apmokejjimas - kai klientas iš anksto apmoka visą užsakymą - teoriškai galètų visiškai eliminuoti riziką. Netiesioginėms priemonėms jie priskirti sąlyginai ir tik todèl, kad nagrinèjamame sektoriuje praktiškai netaikomi.

8 Kai klientas iš anksto apmoka dalị užsakymo.
}

smulkaus ir vidutinio verslo kategorijai, jų pajamos svyruoja nuo 2 iki $50 \mathrm{mln}$. $\mathrm{Lt}^{9}$.

Taigi tyrimo imtis nebuvo atsitiktine, o pasirinkta tikslingai; atsitiktinai pasirinktos tik įmonès, nepriklausančios asociacijai. Imtis nebuvo suformuota atsitiktiniu būdu dèl labai specializuoto tyrimo pobūdžio ir tikètino mažo anketų grižtamumo, nes bandomajame tyrime anketų iš atsitiktiniu būdu parinktų ịmonių grižo labai mažai. Duomenų rinkimą apklausos būdu komplikavo tyrimui atlikti būtini duomenys, kuriems pateikti reikalingos papildomos respondentų pastangos - surinkti įmonès informaciją, apskaičiuoti vidurkius ir pan.

Reikia paminèti, kad apklausti pavyko tik kartotinai išsiuntus anketas (po pirmo karto ju grižo buvo labai mažai), o kai kurioms imonèms - netgi tris kartus. Pastebejome tendenciją, kad i anketas pirma atsake tos ịmonès, kurios turi specializuotą personalą, t. y. kreditų vadybininkus, dirbančius su pirkèjų skolomis.

Kaip jau minèta, su visomis įmonėmis buvo bendrauta telefonu (taip pat ir su tomis, kurios neatsakè). Dažniausia atsisakymo pildyti anketą priežastis - laiko trūkumas, nors labai tikètina, kad už to slypèjo ir nenoras paviešinti finansinius ịmonès duomenis.

Apklaustos įmonès pagal pajamas sudaro daugiau nei pusę smulkių ir vidutinių prekiautojų statybinèmis medžiagomis, todèl gana gerai atstovauja tiriamam objektui.

Tyrimas atliktas $2007 \mathrm{~m}$. pabaigoje remiantis apklaustu imonių pateiktais $2006 \mathrm{~m}$. duomenimis; gauta informacija buvo apdorota ir išanalizuota.

\subsection{Mokèjimo atidèjimo terminai ir vélavimas}

Dažniausiai ̨̨monès, prekiaujančios statybinèmis medžiagomis, savo klientams (kitoms ịmonems) suteikia 30-90 dienu mokejjimo atidejjimo terminus. Būtent šie mokèjimo atidèjimo terminai, sukurdami kreditinius santykius tarp imoniu (kai tiekejjai kredituoja pirkèjus), sukelia ir kredito riziką.

Ar dideli šie kreditai ir ar jie rizikingi? Žinant, kad ịmonès suteikia 30-90 dienų mokèjimo atidèjimo terminus, galima teigti, kad jos nuolat būna suteikusios kreditu, kurių bendra verte siekia nuo $1 / 12^{-o s i o s}$ iki $1 / 4$-osios šiu įmonių metiniu pajamų, tad netgi vidutinio dydžio įmonès, kurių metinès pajamos sudaro $20 \mathrm{mln}$. Lt, savo tiekejjus nuolat kredituoja 2-5 mln. Lt. O bendra metinè suteiktų kreditų suma prilygsta imoniu apyvartai - tad kalbama apie milijardus litų.

Atlikto tyrimo rezultatai rodo, kad įmonių suteikiamų mokejjimo atidejimo terminų vidurkis lygus 41 dienai. Šis skaičius taip pat reiškia, kad tiekejjų kreditas vidutiniškai prilygsta jị suteikiančių ímonių 41 dienos pajamoms - kitaip sakant, $11 \%$ jų metinių pajamų.

Kad ir koks patogus pirkèjams būtų tiekèjo kreditas dažniausiai nemokamas, be jokių ịvykdymo užtikrinimo

\footnotetext{
9 Pagal Europos Komisijos rekomendaciją 2003/361/EC, įsigaliojusią 2005 m. sausio 1 d., SVV kategorijai priklauso ịmonès, kuriose dirba mažiau nei 250 žmonių ir kurių metinè apyvarta neviršija $50 \mathrm{mln}$. eurų ir (arba) metinis balansas neviršija $43 \mathrm{mln}$. eurų.
} 
priemoniu, pirkejjai neretai vis tiek neskuba jo grąžinti laiku (t. y. atsiskaityti praejjus sutartam mokejjimo atidejjimo laikotarpiui): realūs jų atsiskaitymo terminai labai skiriasi nuo tų, kuriuos jiems suteikia tiekejjai. Kitaip sakant, norint sužinoti, kokie yra realūs mokejimo atidejjimo terminai ir kokio dydžio iš tiesų būna tiekèjo kreditas, prie suteiktų mokèjimo atidejjimo terminų dar reikètų pridèti pirkejjų vèlavimus:

Realus mokejjimo atidejimo (atsiskaitymo) terminas = suteiktas mokejjimo atidejimo terminas + vèlavimo trukmé.

Atliktas tyrimas rodo, kad jei suteikti mokejjimo atidejimo terminai vidutiniškai prilygsta 41 dienai, tai vèlavimai vidutiniškai sudaro dar 24 dienas, tokiu būdu tikrasis atsiskaitymo terminas prailginamas iki 65 dienų, t. y. daugiau nei pusantro karto. Kartu tai rodo, kad ir tiekejo kreditas išties pusantro karto didesnis, nei to norètų patys tiekejjai, ir sudaro ne $11 \%$, o $18 \%$ jų metinių pajamų, arba 7 procentiniais punktais daugiau, nei tiekejjai buvo planavę. Kitaip sakant, vèlavimai reiškia, kad tiekejjai ne savo noru ir dar nemokamai nuolat kredituoja savo pirkejus kredito dydžiu, kuris prilygsta $7 \%$ jų metinių pajamų!

1 lenteleje lyginami tyrimo metu nustatyti atsiskaitymų terminai analizuojamame sektoriuje su visų Lietuvos imonių duomenimis (Intrum Justitia 2006).

1 lentelè. Atsiskaitymo terminai statybinių medžiagų prekybos imonèse ir visose Lietuvos įmonèse $2006 \mathrm{~m}$.

Table 1. Terms of payments in building materials trading companies and in all Lithuanian enterprises in 2006

\begin{tabular}{lll}
\hline & $\begin{array}{l}\text { Statybinių } \\
\text { medžiagų } \\
\text { prekybos įmonès }\end{array}$ & $\begin{array}{l}\text { Visos ne finansų } \\
\text { Lietuvos įmonès }\end{array}$ \\
\hline $\begin{array}{l}\text { Vidutinis mokejjimo } \\
\text { atidéjimo terminas, } \\
\text { dienomis }\end{array}$ & 41 & 31 \\
\hline $\begin{array}{l}\text { Vidutinè vèlavimo } \\
\text { trukme, dienomis }\end{array}$ & 24 & 15 \\
\hline $\begin{array}{l}\text { Vidutinè atsiskaitymo } \\
\text { trukme, dienomis }\end{array}$ & 65 & 46 \\
\hline
\end{tabular}

Taigi 2006 m. vidutiniai mokejjimo atidejjimo terminai statybinių medžiagų prekybos įmonèse trečdaliu viršijo Lietuvos vidurkį, o vidutinis atsiskaitymų vèlavimas - net pusantro karto.
Kodèl pirkèjai vèluoja atsiskaityti? Ir ar įmanoma sutrumpinti vèlavimo trukmę? Norint atsakyti į šiuos klausimus, buvo atlikta koreliacinè regresinè analizè (Čekanavičius, Murauskas 2000, 2002) tarp tiekèjų suteiktų mokejjimo atidejjimo terminų ir vèlavimų trukmès. Beje, reikia atkreipti dèmesị, kad analizejje naudoti atskirų imonių duomenys - jau grupiniai vidurkiai, nes anketose ìmonès nurodè vidutinius mokejjimo atidejimo terminus ir vèlavimus, apskaičiuotus remiantis visų savo pirkèjų duomenimis.

Analizuojant buvo siekiama išsiaiškinti, ar suteikti mokejjimo atidejjimo terminai kaip nors veikia vèlavimų trukmę. Atlikus analizę, paaiškejjo, kad ilgesni mokejjimo atidejjimo terminai „užprogramuoja“ ir ilgesnius vèlavimus. Gauti rezultatai pateikti 2 lenteleje, o grafinis vaizdas - 1 pav.

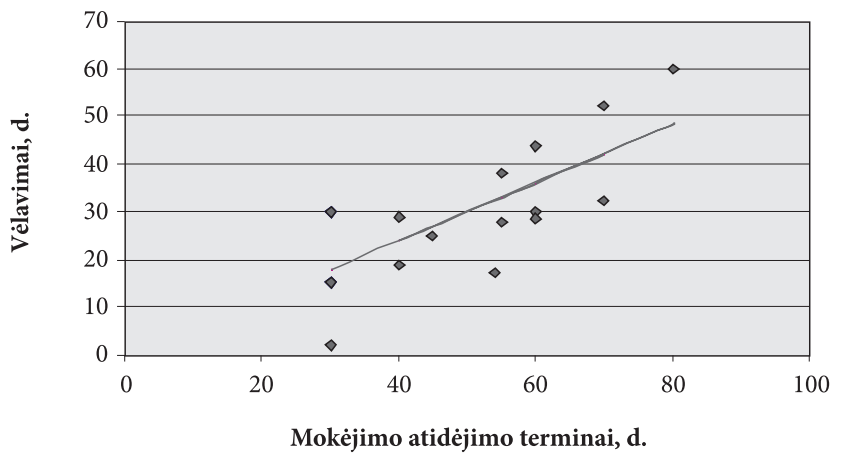

1 pav. Mokejjimo atidejjimo terminų ịtaka vẻlavimų trukmei

Fig. 1. The influence of payment terms on the payment delays

Taigi koreliacijos koeficientas tarp mokejjimo atidejimo terminų ir vèlavimų trukmès yra teigiamas ir stiprus. Be to, determinacijos koeficientas rodo, kad beveik pusę vèlavimų sklaidos galima paaiškinti remiantis mokejjimo atidejjimo terminais. Dar daugiau, regresijos koeficientas $\beta$ netgi parodo, kiek vidutiniškai turètų išaugti vèlavimų trukmè, mokejjimų atidejimų terminą pailginus viena diena - 0,61 dienos. Visi gauti dydžiai statistiškai reikšmingi.

Gauta išvada prieštarauja praktikoje paplitusiam požiūriui, kad vèluoti linkusiems pirkèjams suteikus ilgesnius mokejjimo atidejjimo terminus, jie pradès atsiskaitinèti tvarkingiau ir vėluoti mažiau, kitaip sakant, mokès praejjus tam pačiam terminui, tik tas terminas bus sudarytas iš ilgesnio

2 lentelè. Mokejjimo atidèjimo terminų ittaka vèlavimo trukmei

Table 2. The influence of payment terms on the payment delays

\begin{tabular}{llllll}
\hline Koreliaciné analize & \multicolumn{5}{l}{ Regresinè analizé } \\
\hline koeficientas & reikšmé & reikšmingumo lygmuo & koeficientas & reikšmé & reikšmingumo lygmuo \\
\hline $\begin{array}{l}\text { Koreliacijos } \\
\text { koeficientas }\end{array}$ & 0,70 & $99 \%$ & $\alpha$ & $-0,38$ & $97 \%$ \\
\hline $\begin{array}{l}\text { Determinacijos } \\
\text { koeficientas }\end{array}$ & 0,49 & - & $\beta$ & 0,61 & $98 \%$ \\
\hline
\end{tabular}


3 lentelè. Kreditų vadybininkų užimtumo įtaka atsiskaitymų vèlavimui

Table 3. The influence of being busy of credit managers on the payment delays

\begin{tabular}{llllll}
\hline Koreliacinè analizè & \multicolumn{5}{l}{ Regresinè analizè } \\
\hline koeficientas & reikšmé & reikšmingumo lygmuo & koeficientas & reikšmé & reikšmingumo lygmuo \\
\hline $\begin{array}{l}\text { Koreliacijos } \\
\text { koeficientas }\end{array}$ & 0,55 & $99 \%$ & $\alpha$ & 20 & $99 \%$ \\
\hline $\begin{array}{l}\text { Determinacijos } \\
\text { koeficientas }\end{array}$ & 0,30 & - & $\beta$ & $3,2 \cdot 10^{-7}$ & $99 \%$ \\
\hline
\end{tabular}

atidejimo ir trumpesnio vèlavimo, o idealiu atveju vèlavimas sumažès tiek, kad visiškai kompensuos pailgejusi atidejjimo terminą ar netgi jị viršys (absoliučiu dydžiu), todèl realus atsiskaitymo terminas netgi sutrumpès. Vis dèlto atlikta analizè rodo, kad pailginus mokejjimo atidejjimo terminą, vèlavimai ne sutrumpejja, o, priešingai, pailgejja. Kodèl? Todèl, kad pirkèjų ípročiai nesikeičia ne atsiskaitymo termino ilgio atžvilgiu (t. y. per kiek laiko jie atsiskaito), bet to termino struktūros atžvilgiu, t. y. jei pirkejjas buvo linkęs uždelsti atsiskaitymą pusès suteikto mokèjimo atidejjimo termino ilgiu, jis ir toliau, net ir pailginus atidejjimo terminą, uždels pusę to termino, tik jau ilgesnio.

Žinoma, visai gali būti, kad pailginus mokejimo atidèjimo terminus, iš pradžių pirkèjai atsiskaitys tvarkingiau, tačiau vèliau jie vis tiek apsipras ir grị̌ prie senų ipročių. Tad, Herzbergo žodžiais tariant, mokèjimo atidejjimo termino ilgis nèra motyvuojantis veiksnys, o tik palaikantis ${ }^{10}$ (Herzberg 1964).

Tai yra labai svarbi išvada, nes ji parodo, kad ịmonès, ilgindamos mokejjimų atidejjimo terminus, ne tik nesprendžia vèlavimų problemos, bet ją dar pagilina. O spręsti šią problemą reiketų tuos terminus sutrumpinant arba iš viso kitais būdais: pvz., pasirenkant atitinkamas pirkejjams mažiau laisvės paliekančias atsiskaitymų valdymo priemones, tokias kaip kreditų draudimas, faktoringas ar skolų išieškojimas. Detaliau šios problemos sprendimo būdai bus aptarti vèliau.

Kita svarbi išvada ta, kad suteikdami pirkejams mokèjimo atidejjimo terminus, o ypač norèdami juos pailginti, tiekejai turi žinoti, kad viena suteikta diena realų atsiskaitymo terminą pailgins daugiau nei pusantros dienos.

Dar vienas veiksnys, kuris, tiketina, gali daryti ịtaką vèlavimų trukmei, yra su pirkejjų skolomis dirbančių žmonių skaičius ${ }^{11}$ : logiška manyti, kad, esant mažesniam kreditų vadybininkų skaičiui ${ }^{12}$ ar didesniam jų užimtumui, bus

\footnotetext{
10 Anot Herzbergo motyvavimo teorijos, kad tam tikri veiksniai (jis juos pavadino „higieniniais“) nèra motyvuojantys; jeigu jie yra nepalankūs, sukelia nepasitenkinimą, tačiau jeigu ị juos atsižvelgiama, jie vis tiek netampa pasitenkinimo šaltiniu. Panašiai yra ir su mokejjimų atidejjimo trukme.

11 Toliau tekste - kreditų vadybininkai.

12 Kai yra ta pati pardavimo apimtis
}

sudètingiau išsiieškoti skolas iš pirkejjų ${ }^{13}$. Tuo tikslu buvo atlikta koreliacinè regresinè analizè tarp i̇monès pajamų, tenkančių vienam kreditų vadybininkui, ir atsiskaitymų vèlavimo. Gauti rezultatai pateikti 3 lentelèje.

Apskaičiuotas koreliacijos koeficientas teigiamas, ryšys yra vidutinio stiprumo. Tai reiškia, kad iš tiesų egzistuoja teigiama vidutinio stiprumo priklausomybè tarp pajamų, tenkančių vienam kreditų vadybininkui, ir atsiskaitymų vèlavimų. Vadinasi, atsiskaitymų vèlavimai gali būti susiję su nepakankamais kreditų vadybininkų pajègumais užtikrinti skolų susigrąžinimą laiku. Dar daugiau, galima netgi apytiksliai pasakyti, kad kreditų vadybininkų vidutiniam užimtumui padidejus papildomu milijonu litų ${ }^{14}$, skolų vèlavimas vidutiniškai išaugs 0,32 dienos. Kita vertus, reiketų atkreipti dèmeș $\mathfrak{i}$ tai, kad regresijos reikšmingumas nèra labai didelis, o determinacijos koeficientas, parodantis, kokią dalị reiškinio sklaidos ji paaiškina, - tik 0,3.

Laisvasis regresijos narys rodo, kad „savaiminis“vèlavimas, nepriklausantis nuo kreditų vadybininkų užimtumo, lygus 20 dienų. Ne taip jau mažai, ypač žinant, kad vèlavimų vidurkis siekia 24 dienas. Taigi kreditų vadybininkų užimtumo, priešingai nei suteikiamų mokejjimo atidejjimo terminų, įtaka mokèjimų vèlavimui nèra labai didelè.

Aptarus mokejjimo atidejimo terminų ir darbuotoju užimtumo ịtaką atsiskaitymų vèlavimui, gali kilti klausimas - kodèl tiek daug dèmesio skiriama vèlavimų problemai ir kaip tai susiję su kredito rizika. Iš tiesų atsiskaitymų vèlavimai sukelia dvejopo pobūdžio problemas.

Pirmiausia tai likvidumo problema. Vèluojantys atsiskaitymai sumažina grynųjų pinigų kiekị i̇moneje ir sukelia likvidumo riziką, dèl kurios net pelningai dirbančios i̇monès gali bankrutuoti (beje, netinkamas pinigų srautu valdymas - statistiškai daug dažnesnè įmonių nemokumo ir bankroto priežastis nei nuostolinga veikla). Kitas likvidumo problemos aspektas - finansavimo problema, t. y. papildomų išteklių poreikis finansuoti vèluojančias pirkèjų skolas. Galiausiai tai susiję ir su papildomomis finansinèmis išlai-

\footnotetext{
13 Paprasčiausiai dèl to, kad skolu valdymas ir išieškojimas - labai imlus darbui procesas. O jei dèl laiko trūkumo neatliekamas (arba atliekamas nereguliariai) skambinimas vèluojantiems skolininkams, priminimu rašymas ir pan., tikètina, kad tai paveiks vèlavimų trukmę.

14 Vidutinis jų užimtumas - 15,6 mln. Lt.
} 
4 lentelè. Atsiskaitymų velavimo ịtaka nuostolių dèl pirkejjų nemokumo dydžiui

Table 4 . The influence of payment delays on losses due to buyers' insolvency

\begin{tabular}{llllll}
\hline Koreliacinė analize & \multicolumn{5}{l}{ Regresinè analizé } \\
\hline koeficientas & reikšmé & reikšmingumo lygmuo & koeficientas & reikšmé & reikšmingumo lygmuo \\
\hline $\begin{array}{l}\text { Koreliacijos koefi- } \\
\text { cientas }\end{array}$ & 0,55 & $83 \%$ & $\alpha$ & $-0,0021$ & $80 \%$ \\
\hline $\begin{array}{l}\text { Determinacijos } \\
\text { koeficientas }\end{array}$ & 0,30 & - & $\beta$ & 0,0005 & $83 \%$ \\
\hline
\end{tabular}

domis, nes vèluojančios pirkèjų skolos, kaip kredito forma, papildomų pajamų nesukuria, tačiau jų finansavimas dažniausiai kainuoja (nebent jos būtų finansuojamos vèluojančiomis skolomis tiekejjams, tačiau dažniausias papildomo finansavimo šaltinis - išaugę trumpalaikiai įsipareigojimai bankams, suteikiami kredito linijos ar overdrafto pavidalu). Vis dèlto, kadangi šios problemos tiesiogiai mūsų tyrimo objekto neliečia, jos plačiau ir neanalizuojamos.

Kitas atsiskaitymų vèlavimų aspektas tiesiogiai susijęs su įmonių patiriama kredito rizika, todèl jị ir aptarsime detaliau. Tuo tikslu atlikta koreliacinè regresinè analizè tarp atsiskaitymų vèlavimo ir nuostolių dèl pirkèjų nemokumo. Gauta vidutinio stiprumo teigiama priklausomybe - tikètina, kad pailgèjus vèlavimų trukmei, išaugs ir beviltiškos skolos. Analizès rezultatai pateikti 4 lenteleje ir 2 pav.

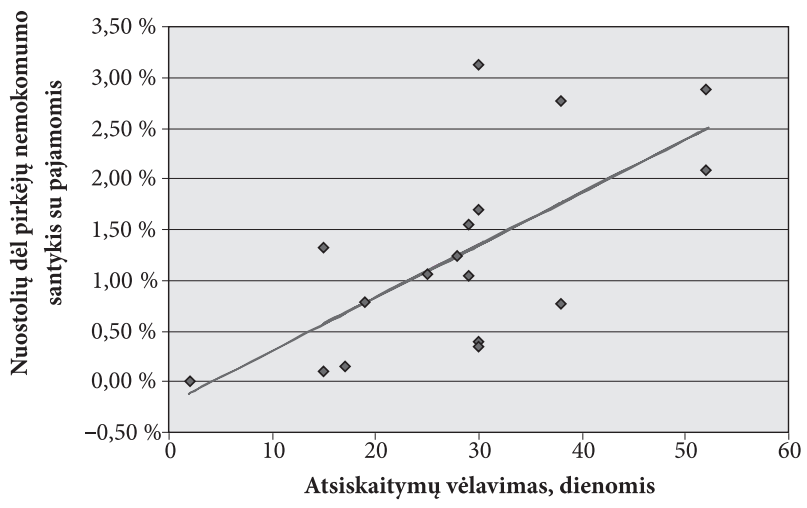

2 pav. Atsiskaitymų vèlavimo įtaka nuostolių dèl pirkèjų nemokumo dydžiui

Fig. 2. The influence of payment delays on losses due to buyers' insolvency

Reikètų atkreipti dèmesî, kad regresinè analizè atlikta tarp vèlavimų trukmès dienomis ir santykinių nuostoliu dèl pirkejų nemokumo: santykiniai nuostoliai apskaičiuoti kaip santykinè įmonių pajamų dalis (nuostolius dèl pirkèjų nemokumo dalijant iš įmonių metinių pajamų), taip sulyginant skirtingo dydžio įmones.

Taigi matyti, kad nuostoliai dèl pirkèjų nemokumo tiesiogiai susiję su vèlavimų trukme: jai padidejus, galima tikètis išaugsiant ir pirmuosius. Galiausiai toks rezultatas nèra ir visai netiketas, nes kiekviena skola, prieš pasidary- dama beviltiška, pirmiausia tampa veluojanti, tad padidejus jų apimčiai, visai natūralu tikètis ir laukti, kad padaugès ir beviltiškų skolų.

Regresijos koeficientas $\beta$ parodo, kad vèlavimo trukmei pailgejus 1 diena, beviltiškos skolos vidutiniškai turètų išaugti 0,0005 įmonès metinių pajamų dalimi, arba 0,05 procentinio punkto.

Kita vertus, gautus rezultatus deretų interpretuoti atsargiai, nes koreliacijos koeficientas tarp dviejų dydžių yra vidutinio stiprumo (determinacijos koeficientas rodo, kad tokiu būdu paaiškinama tik ketvirtis reiškinio sklaidos) ir nera labai patikimas, kaip, beje, ir regresijos koeficientas $\beta$. Regresijos laisvasis narys $\alpha$ yra neigiamas, t. y. galima jo interpretacija, kad nesant vèlavimų, galètų būti uždirbama papildomo pelno.

\subsection{Nuostoliai dèl pirkëjų nemokumo}

Nuostoliai dèl pirkejjų nemokumo tyrime dalyvavusiose imonèse $2006 \mathrm{~m}$. svyravo nuo 0 (beveik penktadalis įmonių teigè $2006 \mathrm{~m}$. nepatyrusios nuostolių dèl pirkèjų nemokumo) iki $5 \%$ pajamų, o vidutiniškai sudarè $0,68 \%{ }^{15}$. Tai iš tiesų labai aukštas rodiklis, net jei spartus ekonominis augimas ir ịmonių plètra kompensuoja ar iš dalies padengia nuostoliu pasekmes.

Vis dèlto nuostolių santykis su pajamomis labai skiriasi ne tik tarp atskirų įmonių, bet ir tarp įmonių grupių. Tad galima išskirti didesnes ir mažesnes įmones. Didesnių i̇monių (t. y. tų įmonių, kurių pajamos viršija bendrą pajamų vidurkị) nuostolingumas sudaro $0,5 \%$, o mažesnių siekia 1,4 \% (atitinkami grupiniai pajamų vidurkiai lygūs 26 ir 7,2 mln. Lt). Taigi skolų valdymas didesnèse įmonèse efektyvesnis ne procentais, o kartais. Priežastis mèginsime nustatyti vèliau.

Tyrimo metu taip pat buvo apskaičiuotas ir nuostoliu dèl pirkejų nemokumo santykis su įmonių bendruoju pel$\mathrm{nu}^{16}$. Šis dydis skirtingose įmonèse svyravo nuo 0 iki $30 \%$, o vidutiniškai sudare 4,6\%. Beje, ši skaičių savo anketose pateikè ne visos įmonès, tad vidurkis buvo apskaičiuotas mažesniam įmonių skaičiui.

\footnotetext{
15 Svertinis aritmetinis vidurkis, apskaičiuotas atsižvelgiant ị ịmonių pajamas.

16 T. y. pelnu prieš veiklos išlaidas (angl. gross profit)
} 
5 lentelè. Imonių dydžio ịtaka nuostolių dèl pirkèjų nemokumo santykiui su bendruoju pelnu

Table 5. The influence of company size on losses due to buyers' insolvency divided by gross profit

\begin{tabular}{llllll}
\hline Koreliacinè analize & \multicolumn{5}{l}{ Regresiné analize } \\
\hline koeficientas & reikšmé & reikšmingumo lygmuo & koeficientas & reikšmé & reikšmingumo lygmuo \\
\hline $\begin{array}{l}\text { Koreliacijos } \\
\text { koeficientas }\end{array}$ & $-0,51$ & $80 \%$ & $\alpha$ & 0,12 & $96 \%$ \\
\hline $\begin{array}{l}\text { Determinacijos } \\
\text { koeficientas }\end{array}$ & 0,26 & - & $\beta$ & $-1,1 \cdot 10^{-9}$ & $80 \%$ \\
\hline
\end{tabular}

Ir vèlgi, jei palygintume didesnes ir mažesnes įmones, tai pamatytume, kad didesnèse įmonèse (t. y. ìmonèse, kurių pajamos viršijo pajamų vidurkị) šis skaičius buvo lygus 2,5\%, o mažesnèse siekè net 18,5\% (atitinkami grupiniai pajamų vidurkiai buvo lygūs 26,1 ir $8,6 \mathrm{mln}$. Lt). Taigi nuostolių santykis su bendruoju pelnu atskirose įmonių grupèse skiriasi dar daugiau nei santykis su pajamomis. Tai reiškia, kad didesnès įmonès ne tik veiksmingiau valdo kredito riziką, bet ir visą veiklą apskritai.

Šią išvadą patvirtino ir atlikta koreliacinè regresinè analizè tarp įmonių dydžio (pajamų) ir nuostolių dèl pirkejų nemokumo santykio su bendruoju pelnu. 5 lentelèje glaustai pateikiami šios analizès rezultatai.

Nustatyta neigiama vidutinio stiprumo priklausomybè tarp i̇monių dydžio ir jų nuostolingumo ${ }^{17}$. Galima netgi teigti, kad įmonių pajamoms išaugus $1 \mathrm{mln}$. Lt, jų nuostolingumas sumažeja 0,0011 pajamų dalimi, arba 0,11 procentinio punkto. Vis delto reikia atkreipti dèmesí, kad regresijos patikimumo lygmuo nedidelis. Kaip dažniausiai ir būna, laisvasis narys šiuo atveju sunkiai interpretuojamas: neigiamas regresijos koeficientas $\alpha$ reikštų, kad esant tam tikram pajamų lygiui (t. y. maždaug $110 \mathrm{mln}$. Lt) nuostoliai dèl pirkejjų nemokumo turètų išnykti, o tai yra netiesa. Tačiau, kaip buvo minèta, tiriamų įmonių pajamos buvo daug mažesnès: nuo 2 iki $50 \mathrm{mln}$. Lt.

Tyrimo metu taip pat buvo patikrinta a priori suformuluota prielaida, kad rizikingesnès yra naujai įsteigtos imonès ${ }^{18}$. Iš tiesų net du trečdaliai apklausoje dalyvavusių imonių patvirtino, kad yra nukentèjusios nuo naujai įsteigtų i̇monių, o penktadalis - nuo įmonių su naujais vadovais. Tačiau nuostoliai, patirti dèl naujų įmonių, buvo nedideli - visos įmonés juos nurodè esant nuo 0 iki $20 \%$ visų nuostolių, patirtų dèl pirkẻjų nemokumo. Tai reiškia, kad tiekejai, parduodami prekes naujoms įmonèms, imasi būtinų atsargumo priemonių.

Kita tikrinama prielaida susijusi su tyčinio nemokumo atvejais. $55 \%$ apklaustų įmonių pripažino, kad joms pasitaiko tyčinio nemokumo atvejų. Vis dèlto nuostoliai dèl tyčinio nemokumo taip pat nèra labai dideli ir neperžengia $20 \%$ visų nuostolių dèl pirkèjų nemokumo.

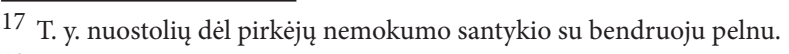

18 İmonès, kurių gyvavimo trukmè neviršija $1 \mathrm{~m}$.
}

İdomūs rezultatai gauti sugretinus įmones, nukentèjusias nuo naujai įsteigtų įmonių ir nuo tyčinio nemokumo atvejų: net $71 \%$ įmonių, nukentejusių nuo naujų imonių, nukentejjo ir nuo tyčinio nemokumo atvejų. Tai patvirtina prielaidą, kad sukčiavimas dažnesnis tarp naujai įsteigtų įmonių. Ir iš tiesų pasitaiko tokių ịmonių, kurios isteigiamos tik sukčiavimo tikslais: kreditan prisipirkusios (tiksliau, pasiemusios) medžiagų, jos subankrutuoja dar nesuejjus mokèjimo atidèjimo terminui.

\section{Problemų sprendimo būdai naudojant ịvairias kredito rizikos valdymo priemones}

\subsection{Kredito rizikos valdymo priemoniu naudojimo analize}

Ankstesniame skyrelyje matėme, kad atsiskaitymų vèlavimai gali sukelti nuostolių dèl pirkèjų nemokumo. Tačiau kokių veiksmų įmonès imasi, kad tų nuostolių išvengtų, kokias rizikos valdymo priemones jos naudoja? Ǐs anketoje pateiktų 17 rizikos valdymo priemonių įmonès respondentès kaip naudojamas pažymèjo tik 11 . Toliau pateiktoje diagramoje (3 pav.) apibendrintai vaizduojami imoniu pateikti atsakymai.

Paaiškèjo, kad realiai įmonès naudoja tik 7 kredito rizikos valdymo priemones, dar 4 - retai, o 6 (akredityvine atsiskaitymų forma, dokumentų inkasavimas, hipoteka, ikeitimas, garantija ir forfeitingas) iš viso nenaudojamos ${ }^{19}$.

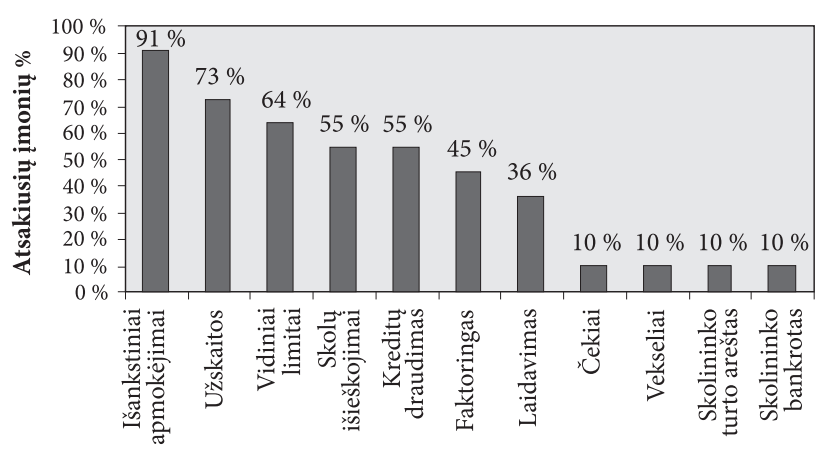

3 pav. Kredito rizikos valdymo priemonių naudojimo mastas

Fig. 3. The use of instruments of credit risk management

$\overline{19}$ Nenaudojamos kredito rizikai valdyti, o ne apskritai. 
Taigi absoliuti dauguma įmonių reikalauja iš savo klientų išankstinių mokejjimų, du trečdaliai vykdo užskaitas ir taiko vidinius kredito limitus savo pirkèjams. Visi šie būdai juos taikančioms įmonèms nieko nekainuoja, gal todèl jie ir populiariausi (prie rizikos valdymo priemonių pasirinkimo motyvų grižžtama 4 skyrelyje). Po jų eina skolų išieškojimas, kreditų draudimas ir faktoringas - juos taiko apie pusè visu apklausoje dalyvavusių įmonių, o laidavimą - apie trečdali. Čekinè, vekselinè atsiskaitymų formos, skolininko turto areštas ir uždelsto įsiskolinimo išieškojimas paskelbiant skolininkui bankrotą (kai bankrotas skolininkui paskelbiamas tiekejo iniciatyva) naudojami labai retai, nes tai sudètingos ir, reikia pripažinti, ne visada veiksmingos procedūros.

Kitas svarbus klausimas - išsiaiškinti naudojamų kredito rizikos valdymo priemonių derinius, t. y. kokios priemonès su kokiomis naudojamos - juk nè viena priemonè nèra naudojama pati viena, atskirai nuo kitų, dažniau naudojamas visas jų rinkinys. Taigi su vidiniais limitais beveik visada naudojami išankstiniai mokejjimai: pirmieji daugiau taikomi didmeninëje prekyboje, o antrieji - mažmeninejje; su skolų išieškojimu visada naudojamos užskaitos (skolų išieškojimo agentūrų verčiami skolininkai dažnai atsiskaito ne pinigais, o prekemis ar darbais). Taip pat su skolu išieškojimu 50 \% atvejų naudojamas kreditų draudimas ir faktoringas, o su užskaitomis (taip pat $50 \%$ atvejų) - kreditų draudimas ir laidavimas. Taip yra dèl to, kad nei skolu išieškojimas, nei užskaitų naudojimas patys vieni kredito rizikos visiškai išvengti nepadeda, nes taikomi jau skolai atsiradus. Todèl kartu su jais naudojamos tokios rizikos valdymo priemonès, kurios skolas „apdraudžia“ dar prieš jų atsiradimą, t. y. kreditų draudimas, faktoringas ir laidavimas. Kita vertus, šios priemonès, nors ir padètų visiškai išvengti rizikos, pačios vienos taip pat nenaudojamos todèl, kad yra brangios, o kartu taikant užskaitas, išlaidos sumažejja, nes už dalį skolų nebereikia mokèti nei draudimo, nei faktoringo mokesčių.

Vis dèlto anksčiau pateikta diagrama (3 pav.) nerodo, kaip dažnai naudojamos išvardintos priemonès. Pvz., visai gali būti, kad skolų išieškojimas, nors jị ir naudoja daugiau nei pusè apklaustų i̇monių, kasdienëje veikloje taikomas

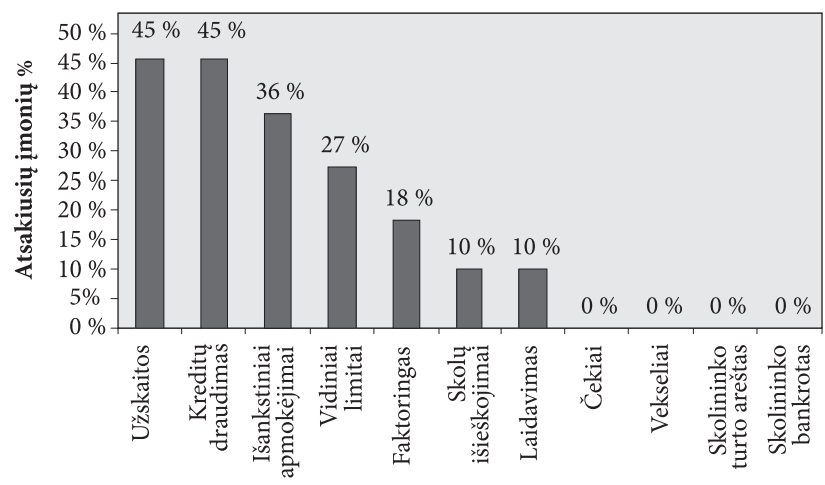

4 pav. Dažnai naudojamos kredito rizikos valdymo priemonès

Fig. 4. Frequently used instruments of credit risk management retai, vos kartą kitą per metus, o kreditų draudimas, kurị taip pat deklaravo naudojančios $55 \%$ įmonių, naudojamas kasdien. Ši aspektą patikslina 4 pav. pateikta diagrama.

Kaip dažniausiai naudojamas kredito rizikos valdymo priemones daugiausia i̇monių paminėjo užskaitas ir kreditų draudimą. Po jų èjo išankstiniai mokejimai, vidiniai kredito limitai, faktoringas ir skolų išieškojimas su laidavimu. Čekių, vekselių, skolininko turto arešto ir bankroto paskelbimo skolininkui nepaminejjo nè viena įmonè.

Palyginus dvi anksčiau pateiktas diagramas (5 pav.), galima pastebėti, kad išankstiniai apmokèjimai, nors ir naudojami didžiausio įmonių skaičiaus, kasdienèje veikloje taikomi rečiau už antroje vietoje pagal naudotojų skaičių atsidūrusias užskaitas.

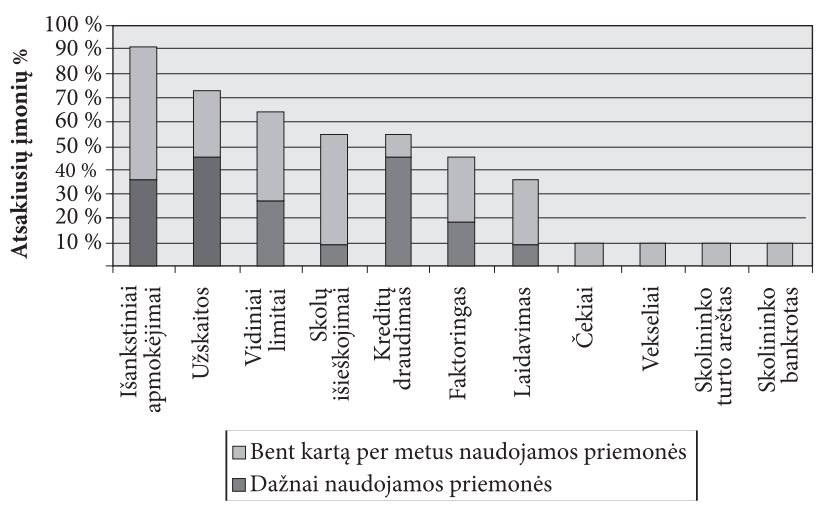

5 pav. Kredito rizikos valdymo priemonių naudojimo dažnumas

Fig. 5. The frequency of use of credit risk management instruments

Kreditų draudimas, pagal naudotojų skaičiu vos pakliūnantis ì penketuką, išsiskiria kaip dažniausiai naudojama priemonè: iš tiesų beveik visos įmonès, kurios nurodè naudojančios kreditų draudimą, ji taip pat pažymèjo ir kaip dažniausiai naudojamą priemonę.

Tokios priemonès, kaip vidiniai įmonių kredito limitai ar skolų išieškojimas, turi daug naudotojų, tačiau kasdienèje veikloje taikomos gan retai. Taip yra todèl, kad nei viena, nei kita priemonè nuo kredito rizikos visiškai neapsaugo.

Panaši ị kreditų draudimą situacija ir su faktoringu: atsidūręs šeštoje vietoje pagal naudojančių i̇monių skaičių, pagal naudojimo dažnumą jis lenkia skolų išieškojimą, esantị ketvirtoje vietoje. Jam pagal naudojimo dažnumą prilygsta laidavimas, nors pagal naudotojų skaičių jis yra tik septintoje vietoje.

Galiausiai reikia atkreipti dèmesị ir $\mathfrak{x}$ tai, kad net tos kredito rizikos valdymo priemonès, kurios turi tą patị naudotojų skaičių ir dažnį, gali būti naudojamos skirtingų i̇monių. 6 pav. diagramoje vaizduojama įmonių dydžio įtaką priemonių pasirinkimui, t. y. kokie yra kiekvieną kredito rizikos valdymo priemonę naudojančių įmonių grupių pajamų vidurkiai. 


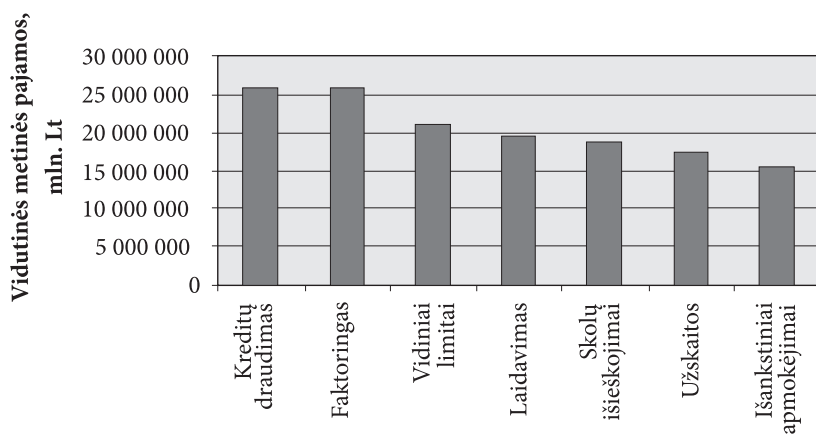

6 pav. Kredito rizikos valdymo priemonių naudotojai pagal metinių pajamų dydị

Fig. 6. The users of credit risk management instruments according to their annual income

Matyti, kad sudetingesnes ir brangesnes priemones, tokias kaip kreditų draudimas ar faktoringas, naudoja didesnès įmonès, o paprastesnes ir pigesnes, tokias kaip užskaitos ar išankstiniai mokejjimai, taiko mažesnès ịmonès - tai gali būti atsakymas ị klausimą, kodèl taip skiriasi nuostoliai dèl pirkèjų nemokumo skirtingo dydžio ịmonèse ${ }^{20}$.

\subsection{Kredito rizikos valdymo priemoniu efektyvumas}

Kaip buvo minèta, vidutinis įmonių suteikiamas mokèjimo atidejimo terminas sudaro 41 dieną, o dar vidutiniškai 24 dienas pirkejjai vèluoja atsiskaityti. Norint nustatyti kredito rizikos valdymo priemonių veiksmingumą, buvo apskaičiuota, kaip keičiasi vidutinè mokejjimo atidejjimo terminų trukmè įmonèse, taikančiose įvairias kredito rizikos valdymo priemones. Analogiškai buvo apskaičiuotos ir vidutinès vèlavimo trukmès. Gauti rezultatai parodè, kad dauguma priemonių reikšmingai sumažina abu terminus (7 pav.).

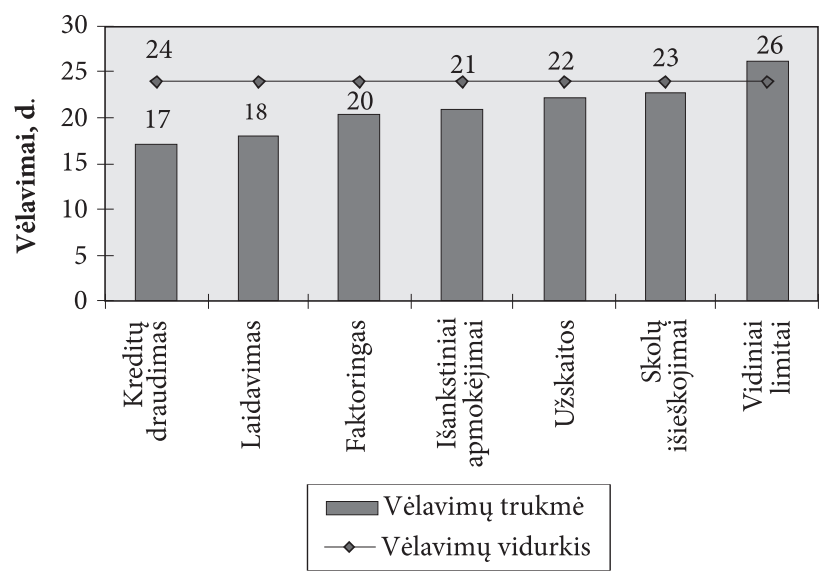

7 pav. Kredito rizikos valdymo priemonių ịtaka vèlavimo trukmei

Fig. 7. The influence of credit risk management instruments on the term of delays

\footnotetext{
${ }^{20}$ Detalesni paaiškinimai apie nuostolių dèl pirkèjų nemokumo dydị buvo pateikti 2.3 skyrelyje.
}

Iš tiesų praktiškai bet kokių kredito rizikos valdymo priemonių naudojimas padeda sumažinti vidutinę vèlavimo trukmę. Išimtis - tik vidiniai įmonių kredito limitai, nes jie, apribodami kredito riziką, iš tiesų neturi jokios įtakos vèlavimo prevencijai. Tam, kad sumažintų vèlavimus, jie turi būti naudojami kartu su kitomis priemonèmis, pvz., kreditų draudimu. Tokiu atveju, jei paimtume įmones, kurios naudoja ir vidinius skolinimo limitus ir kreditų draudimą, vidutinè vèlavimo trukmé būtų lygi 16 dienų, t. y. būtų gautas pats geriausias rezultatas ${ }^{21}$.

Taip pat galima pabrèžti, kad labiausiai vèlavimus sumažina kreditų draudimo, laidavimo ir faktoringo naudojimas, t. y. tų priemonių, kurios ị atsiskaitymų procesą įtraukia trečiąją šalị. Trečiosios šalies įtraukimas padeda sukurti „atsiskaitymų discipliną“, kai skolininkas žino, kad kreditorius, laiku nesulaukęs apmokèjimo, dèl atsiskaitymo galès kreiptis ị trečiąją šalį - draudiką, laiduotoją ar faktorių.

Gali kilti klausimas, kodèl prie trijų paminètų priemonių nepatenka skolų išieškojimas, kuris taip pat susijęs su trečiąja šalimi. Atsakymas galètų būti, kad skolų išieškojimo atveju ta trečioji šalis nèra koks nors naujas („trečias") mokètojas, o veikia tik kaip tarpininkas.

Panašią analizę galima atlikti ir su mokejjimo atidejjimo terminais, parodant, kad kredito rizikos valdymo priemonių naudojimas „sutrumpina“ ir mokejjimo atidejjimo terminus (arba, kitaip sakant, ịmonès, taikančios ịvairias rizikos valdymo priemones, taiko ir trumpesnius mokejjimo atidejimo terminus). Tai ir vel tinka visoms priemonèms, išskyrus vidinius įmonių skolinimo limitus. Kokiu būdu kredito rizikos valdymo priemonès ịpareigoja tiekèjus sutrumpinti mokejjimo atidejjimo terminus savo pirkejjams? Pvz., faktoringas nustato maksimalius kreditavimo terminus, kreditų draudimas numato maksimalų mokejjimo atidejimo terminą, o užskaitų naudojimas tuos terminus iš viso sutrumpina iki nulio.

Taigi įmonèse, kurios naudoja kredito rizikos valdymo priemones, trumpesni ir mokejimo atidejimo terminai, ir vèlavimai, todèl galima sakyti, kad kredito rizikos valdymo priemonés galutinius atsiskaitymo terminus veikia dviem kanalais: pirma, tos įmonès, kurios naudoja priemones, taiko trumpesnius mokejjimo atidejimo terminus; antra, priemonių naudojimas sutrumpina ir vèlavimus. Taigi čia galètų būti vienas iš paaiškinimų, kodèl trumpesni mokèjimo atidejimo terminai susiję su mažesniais vèlavimais: paprasčiausiai tiek už vienų, tiek už kitų slypi rizikos valdymo priemonès, kurios ta pačia kryptimi veikia ir suteikiamus mokejimo atidejjimo terminus, ir vèlavimus.

\footnotetext{
${ }^{21}$ Gali kilti klausimas, kokiu būdu gaunamas 16 dienų vidurkis, jei vidurkis kreditų draudimą naudojančiose ịmonèse yra 17 dienų, o vidinius skolinimo limitus - 26. Iš tiesų naujasis vidurkis apskaičiuojamas iš mažesnio skaičiaus efektyviau dirbančių įmonių, nes ne visos įmonès, kurios taiko vieną arba kitą priemonę, taiko jas abi iš karto.
} 


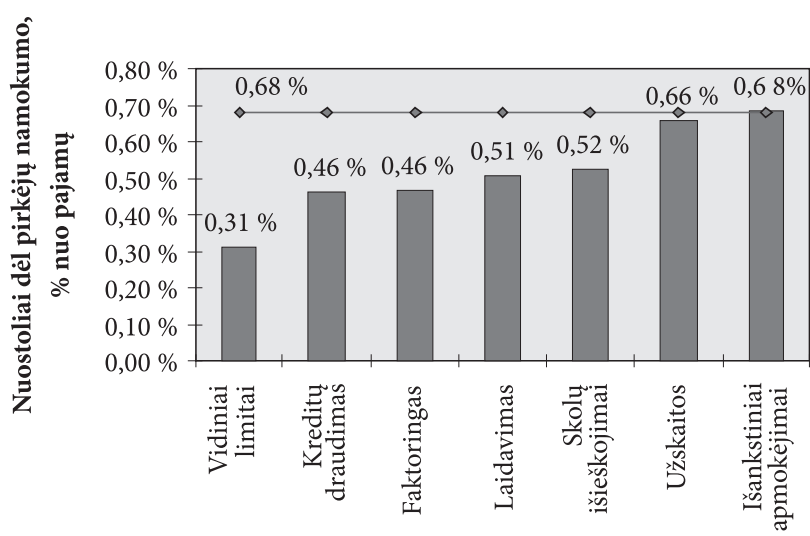

8 pav. Kredito rizikos valdymo priemonių ịtaka nuostoliams dèl pirkèjų nemokumo

Fig. 8. The influence of credit risk management instruments on the losses due to insolvency of buyers

Vis dèlto kredito rizikos valdymo priemonès reikšmingai veikia ne tik vèlavimų ar mokejjimo atidejjimo terminų trukmę, bet ir nuostolių dèl pirkèjų nemokumo dydị. 8 pav. pateiktoje diagramoje matyti kredito rizikos valdymo priemonių ittaka nuostolingumui ${ }^{22}$, t. y. kaip įvairių rizikos valdymo priemonių naudojimas paveikia nuostolius dèl pirkejų nemokumo.

Matyti, kad bet kokios naudojamos priemonès sumažina ịmonių patiriamus nuostolius. Taigi tai galètų būti pirmas atsakymas ị klausimą - kaip sumažinti nuostolius, patiriamus dèl pirkèjų nemokumo: pradèti naudoti rizikos valdymo priemones, iš pradžių net nèra taip svarbu kokias, nes bet kokios naudojamos priemonès duos teigiamų rezultatų. Tad svarbu pradèti, o jau paskui galima analizuoti, kurios iš tų priemonių efektyvesnès, pigesnès, paprastesnes ir t. t.

Kartu ši diagrama - ir kredito rizikos valdymo priemonių efektyvumo matas, nes rodo, kurios priemonès nuostolius sumažina labiau. Gauti rezultatai panašūs ị rizikos valdymo priemonių naudojimo įtaką vèlavimų trukmei (7 pav.), t. y. ir vèl išsiskiria tos pačios priemonių grupès: kreditų draudimas, faktoringas ir laidavimas, netoli jų skolų išieškojimas, o užskaitos su išankstiniais apmokejjimais gerokai atsilieka.

Tačiau būtina atkreipti dèmesị, kad tik penktadaliui apklaustų i̇monių klientų nemokumo atveju iš trečiosios šalies pavyksta susigrąžinti visas skolas. Dar du penktadaliai teigia gebantys atgauti daugiau negu pusę skolų. Kalbant vien tik apie kreditų draudimą, net du trečdaliai apklaustų imonių pripažino, kad draudikai jiems yra sumažinę draudimo išmoką arba iš viso atsisakę ją išmokèti. Dažniausios tokių atsisakymų priežastys - draudimo taisyklių pažeidimai, nesilaikant draudimo sutartyje numatytų terminų ar kitų sąlygų, kitaip sakant, įmonès darbuotojų klaidos. Kita

\footnotetext{
$\overline{22}$ Nuostolių dèl pirkejų nemokumo santykiui su pajamomis.
}

vertus, matyti, kad net ir su nešimtaprocentiniais skolų grąžinimo rodikliais šios priemonès užima pirmąsias vietas efektyviausių priemonių rikiuoteje.

İdomi situacija su vidiniais įmonių kredito limitais: vèlavimų prevencijoje užèmę paskutinę vietą, mažinant nuostolingumą, jie patenka ị pirmąją. Kaip jau minèta, taip gali būti dèl to, kad vidiniai limitai išties nedaro jokios ittakos pirkejų atsiskaitymo laikui, tačiau puikiai tinka siekiant apriboti potencialų nuostolių dèl pirkejų nemokumo dydį.

Aptarus kredito rizikos valdymo priemonių įtaką vèlavimams ir nuostolingumui bei nustačius, kurios iš priemonių efektyviausios, gautus rezultatus verta palyginti su, imonių nuomone, efektyviausiomis priemonemis ${ }^{23} .9$ pav. pateiktoje diagramoje matyti, kurias iš naudojamų priemonių įmonès laiko esant efektyviausias.

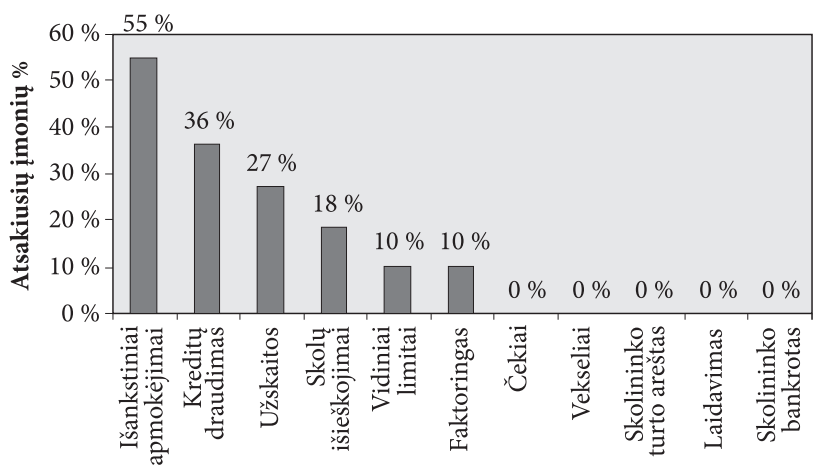

9 pav. Efektyviausios, įmonių nuomone, kredito rizikos valdymo priemonès

Fig. 9. The most effective credit risk management instruments, in companies' opinion

Imonès labiausiai vertina išankstinius mokèjimus, nors atlikti skaičiavimai parodè, kad iš tiesų ši priemonè nèra tokia efektyvi, kaip įmonès galvoja: ji užèmè ketvirtą vietą vèlavimų prevencijoje (7 pav.) ir tik septintą - paskutinę vietą mažinant nuostolingumą (8 pav.).

Antroje vietoje, įmonių vertinimu, atsidūrẻ kreditų draudimas, ir tai maždaug atitinka analizès rezultatus (pirma vieta tarp vèlavimų ir antra - tarp nuostolingumo). Užskaitas ir skolų išieškojimą įmonès akivaizdžiai pervertina, vidinių limitų vertinimas maždaug atitinka jų padètį vèlavimų diagramoje, o faktoringą ir laidavimą - dvi iš efektyviausių priemonių - įmonès labai nuvertina, pvz., laidavimo nauda netiki né viena įmoné. Toks rezultatas gali būti susijęs su sudètingu laidavimo taikymu praktikoje (nors iš tiesų ne tiek sudètinga jị taikyti, kiek pareikalauti iš pirkèjo, kad turètų laiduotoją, o ypač esamos konkurencijos sąlygomis, kai pirkejjai labai lengvai gali pasirinkti ne tokị reiklų pardavejją).

Apibendrinant galima pasakyti, kad tos kredito rizikos valdymo priemonès, kurias pačios įmonès laiko efekty-

\footnotetext{
${ }^{23}$ Pagal atsakymą i anketos klausimą „Kuri (-ios) iš pirmiau išvardintų priemonių Jums atrodo efektyviausia (-ios)?”
} 
viausiomis, kaip rodo atliktas tyrimas, iš tiesų nèra efektyviausios. Paprasčiausiai įmonių atsakymai ị klausimą „Kuri (-ios) iš pirmiau išvardintų priemonių Jums atrodo efektyviausia (-ios)?" pagrissti ne skaičiavimais, o priemoniu taikymu kasdienëje praktikoje. Jei palygintume 9 ir 3 pav., rastume daug panašumų. Kitaip sakant, efektyviausiomis priemonemis įmonès laiko tas, kurias jos pačios taiko ir kurias gerai supranta.

\section{Imonèms priimtino kredito rizikos lygio tyrimas}

Tyrimas parodé, kokias kredito rizikos valdymo priemones įmonès taiko savo veikloje, kurios iš tų priemonių naudojamos dažniau ir kurios veiksmingesnès. Vis dèlto nereikia pamiršti, kad ne visos įmonés taiko rizikos valdymo priemones, o ir tos, kurios jas taiko, - ne visiems pardavimo atvejams. Todèl tyrimas buvo pratęstas ir atlikta detalesnè „priemonių netaikymo" analizè, t. y. kokiai daliai pardavimo i̇monès netaiko jokių kredito rizikos valdymo priemonių ir kokios priežastys lemia tokị jų sprendimą, kokiems pirkèjams įmonès labiau linkusios parduoti prekes savo rizika bei kaip priimtinas rizikos lygis veikia kredito rizikos valdymo priemonių pasirinkimą ir atsiskaitymų sąlygas.

Pateikiamame 10 pav. vaizduojamas įmonėms priimtinas kredito rizikos lygis, t. y. kokiai daliai pardavimo įmonès netaiko jokių rizikos valdymo priemonių.

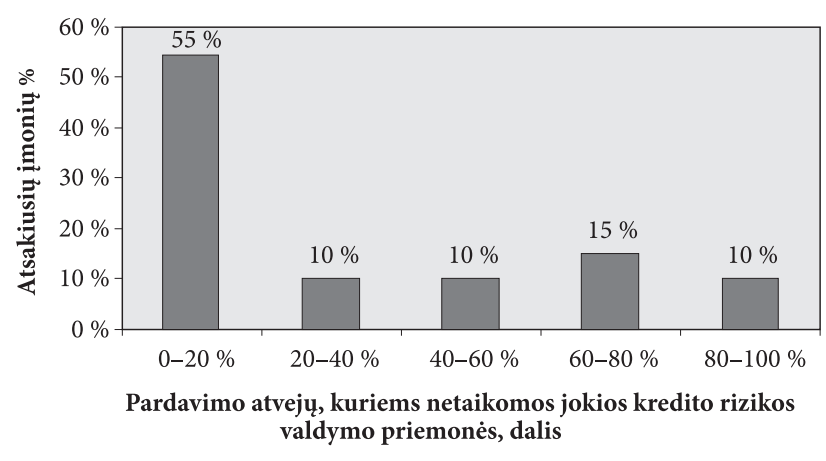

10 pav. Imonèms priimtinas kredito rizikos lygis

Fig. 10. The acceptable credit risk level for companies

Daugiau nei pusei įmonių yra nepriimtina bet kokia su pardavimu susijusi kredito rizika. Apie trečdalis įmonių savo rizika pirkejjams parduoda daugiau nei pusę prekių. Kodèl taip skiriasi įmonèms priimtinas kredito rizikos lygis ir nuo ko jis priklauso? Atliktas tyrimas rodo, kad didesnį rizikos lygị prisiimti linkusios mažesnès ịmonès: jei palygintume įmones, kurios iš viso neparduoda prekių savo rizika, su ịmonèmis, kurios sutinka prisiimti tam tikrą riziką, pamatytume, kad šių dviejų grupių įmonių pajamų vidurkiai skiriasi maždaug du su puse karto (atitinkamai 19,2 ir 7,2 mln. Lt).
Kitas klausimas - kodèl įmonès (dabar jau žinome, kad tai mažesnès įmonès) kredito rizikos valdymo priemones taiko ne visiems pardavimo atvejams? $60 \%$ iš jų taip elgiasi dèl to, kad kredito rizikos priemonių taikymas brangiai kainuoja, o 40 \% - dèl laiko sąnaudų. Vadinasi, kredito rizikos valdymo priemonių pasirinkimą reikšmingai veikia kaina ir laikas.

Jei, kaip rodo tyrimo rezultatai, dalis įmonių kredito riziką mažinančias priemones taiko ne visiems pardavimo atvejams, tuomet gali kilti klausimas - kuriems pirkejams įmonès tų priemonių netaiko. 11 pav. pateiktoje diagramoje vaizduojami įmonių atsakymai ị ši klausimą (kai pasirinkimo variantai duoti).

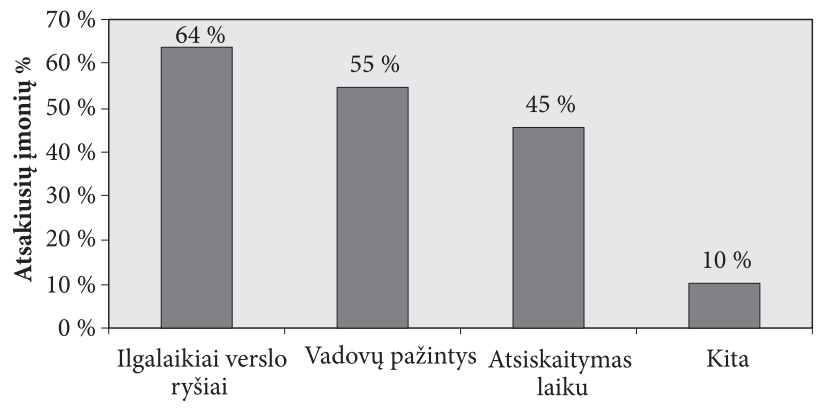

11 pav. Pirkejjai, kuriems įmonès netaiko kredito riziką mažinančių priemonių

Fig. 11. Buyers, to which companies do not apply credit risk reducing instruments

Kaip matome, svarbiausia priežastimi ịmonès ịvardija ilgalaikius verslo ryšius su klientais, antroje vietoje - asmeninès vadovų pažintys (kai vadovai pažista vadovus) ir tik trečioje - sąskaitų apmokẻjimas ne vèliau nei nustatytas terminas. Galima teigti, kad toks ịmonių pasirinkimas labai rizikingas, nes daugiau nei pusė i̇monių, savo rizika parduodančių prekes pirkèjams, su kuriais jas sieja ilgalaikiai verslo ryšiai ar asmeninès vadovų pažintys, prisipažino nuo jų nukentejusios. Kita vertus, nuostoliai, susiję su nemokiomis pažistamomis įmonemis, nèra dideli: jie neviršija $20 \%$ visų nuostolių, kuriuos įmonès patiria dèl pirkejjų nemokumo.

Kad dalis įmonių linkusios rizikuoti, taip pat atskleidžia faktas, jog tik mažiau nei trečdalis įmonių neparduotų pirkẻjams, apie kuriuos turi išankstinès neigiamos informacijos. Kitos būtų linkusios rizikuoti ir parduoti neviršydamos išankstinio mokejjimo, kreditų draudimo ar faktoringo suteikto limito ribų.

Jei tam tikros įmonès kredito rizikos valdymo priemones taiko ne visiems pirkejjams dèl kainos ar laiko, kuo jau ịsitikinome, vadinasi, turètų būti esminių skirtumų tarp tų priemonių, kurias savo veikloje taiko šios įmonès, ir tų priemonių, kurias taiko visiškai kredito rizikos siekiančios 


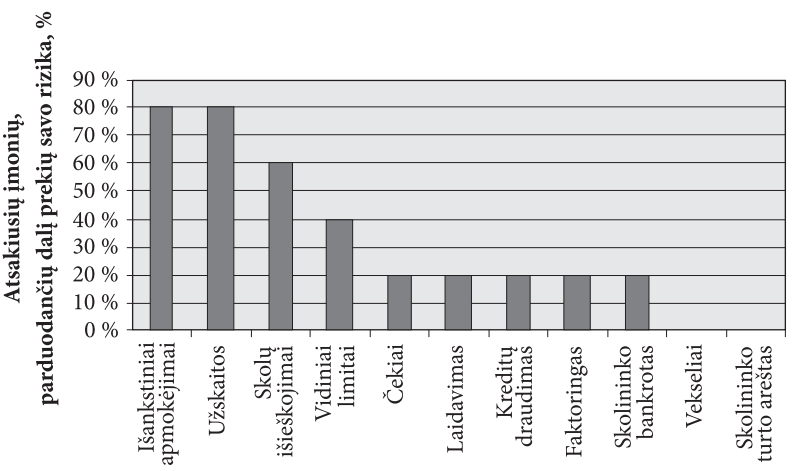

12 pav. Kredito rizikos valdymo priemonès, kurias naudoja dalị prekių savo rizika parduodančios įmonès

Fig. 12. Credit risk managing instruments used by companies which sell part of goods at their own risk

išvengti ịmonès (tai, beje, joms taip pat nepavyksta ${ }^{24}$ ). $12 \mathrm{ir}$ 13 pav. matyti, kokias kredito rizikos valdymo priemones naudoja vienos ir kitos įmonès.

Taigi įmonès, parduodančios dali prekių savo rizika, daugiausia naudoja išankstinius apmokejimus, užskaitas, skolų išieškojimą ir vidinius limitus, t. y. paprastas ir nebrangias priemones (išskyrus skolų išieškojimą, tačiau ši priemonè paprasta ir nebrangi ta prasme, kad, skirtingai nei kreditų draudimas, faktoringas ar laidavimas, kurie taikomi iš anksto ir visiems pardavimo atvejams, skolų išieškojimas naudojamas jau pasireiškus rizikai ir tik nedidelei pardavimo daliai). Savo rizika prekių neparduodančios imonès kartu su keturiomis jau minètomis priemonèmis papildomai taiko ir sudètingesnes bei brangesnes: kreditu draudimą, faktoringą ir laidavimą ${ }^{25}$.

Kitas aspektas, išskiriantis įmones, parduodančias dali prekių savo rizika ir jų neparduodančias, - klientų atsiskaitymo sąlygos, t. y. klientams suteikiami mokèjimo atidèjimo terminai ir klientų vèlavimas. Jų lyginimas pateiktas 6 lentelèje.

Imonès, dalį prekių parduodančios savo rizika, klientams taiko ilgesnius mokèjimo atidèjimo terminus ir, be to, susiduria su ilgesniais vèlavimais, nes nesugeba priversti skolininku atsiskaityti laiku. Kaip rodo 12 pav., jos beveik nenaudoja

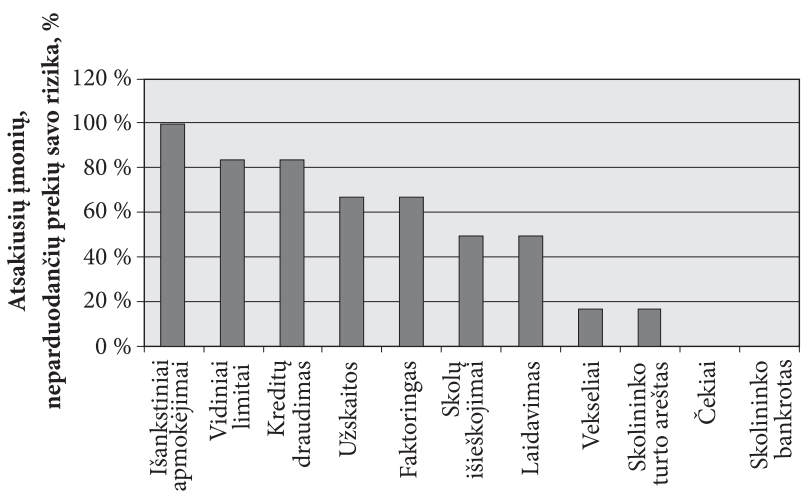

13 pav. Kredito rizikos valdymo priemonès, kurias naudoja savo rizika prekių neparduodančios įmonès

Fig. 13. Credit risk managing instruments used by companies which do not sell goods at their own risk

„trečiąą̨ šalį ịtraukiančių atsiskaitymų valdymo priemonių, kurios, kaip mateme 7 pav., labiausiai ir padeda apsisaugoti nuo vèlavimo, sukurdamos , atsiskaitymų discipliną“.

Šių dviejų i̇monių grupių nuostolingumas skiriasi ir dèl pirkèjų nemokumo (t. y. nuostolių dèl pirkejjų nemokumo santykis su pajamomis): jis lygus vidutiniškai 0,36 \% imonèse, taikančiose kredito rizikos valdymo priemones visiems pardavimo atvejams, ir net 1,94\% tose imonèse, kurios priemones taiko ne visiems pardavimo atvejams. Matyti, kad imonių, kurios rizikos valdymo priemones taiko ne visiems pardavimo atvejams, nuostolingumas kelis kartus didesnis nei tų, kurios tas priemones taiko visiems pardavimo atvejams.

Taigi „priemonių nenaudojimo“ analizè leidžia išskirti dvi ịmonių grupes, kurių vieną apibrèžia didesnè pardavimo apimtis savo rizika ir paprastesnès bei pigesnès kredito rizikos valdymo priemonès bei ilgesni mokejjimo atidejjimo terminai ir vélavimas, o kitą - vengimas parduoti prekes savo rizika, brangesnès ir sudètingesnès priemonès ir atitinkamai trumpesni mokejjimo atidejjimo terminai bei vèlavimas. Kaip jau matème, pirmos grupès įmonès vidutiniškai 2-3 kartus mažesnès nei antros ir kelis kartus nuostolingesnès.

6 lentelè. Atsiskaitymo sąlygos įmonėse, parduodančiose dali prekių savo rizika ir jų neparduodančiuose

Table 6. Conditions of settlements in companies which sell part of goods at their own risk and which do not

\begin{tabular}{llll}
\hline & $\begin{array}{l}\text { Imonès, dali prekių } \\
\text { parduodančios savo rizika }\end{array}$ & $\begin{array}{l}\text { Imonės, prekių savo rizika } \\
\text { neparduodančios }\end{array}$ & Visos tyrime dalyvavusios ịmonès \\
\hline $\begin{array}{l}\text { Vidutinis mokèjimo } \\
\text { atidejjimo terminas, } \\
\text { dienomis }\end{array}$ & 49 & 34 & 41 \\
\hline $\begin{array}{l}\text { Vidutine vèlavimo } \\
\text { trukmé, dienomis }\end{array}$ & 32 & 18 & 24 \\
\hline
\end{tabular}

\footnotetext{
${ }^{24}$ Ir viena iš to priežasčių, kaip jau minèta, - darbuotojų klaidos.

${ }^{25}$ Iš tiesų jau anksčiau buvo galima pastebèti, kad abi charakteristikos (sudetingesnès kredito rizikos valdymo priemonès ir mažesnis priimtinas kredito rizikos lygis) susijusios, nes jos abi buvo būdingos didesnèms įmonèms.
} 


\section{Išvados}

1. Kredito rizika atsiranda tuomet, kai vienas iš verslo partnerių kitam suteikia prekini (tiekejjo) kreditą. Tokiu atveju kyla rizika, kad skolininkas nesilaikys sutarto atsiskaitymų grafiko arba su kreditoriumi neatsiskaitys iš viso.

2. Kredito rizikos priežastys gali būti tyčinès ir objektyvios. Abiem atvejais daug ittakos turi informacijos asimetrija tarp pirkejo ir pardavejjo. Tyčinio nemokumo atveju didesnę grèsmę kelia naujos įmonès. Kita didesnès rizikos įmonių grupè - smulkesnès pagal turtą, pajamas ar darbuotojų skaičiu įmonès.

3. Egzistuoja daug ir įvairių kredito rizikos mažinimo priemonių. Vienos iš jų gali būti naudojamos savarankiškai, o kitos kredito riziką mažina tik netiesiogiai, todèl jas rekomenduojama taikyti kartu su pirmosiomis.

4. Kai kurias kredito rizikos mažinimo priemones lengva naudoti, bet jos negarantuoja visiškos apsaugos (išankstiniai mokèjimai, skolų išieškojimas, užskaitos, vidiniai kredito limitai), o kitos užtikrina visišką apsaugą, bet sunkiau pritaikomos (hipoteka, ikeitimas, garantija, laidavimas).

5. Kaip rodo atlikto tyrimo rezultatai, vidutinè atsiskaitymų trukmé Lietuvos statybinių medžiagų prekybos įmonèse $2006 \mathrm{~m}$. siekè 65 dienas, iš kurių 24 sudarè pirkejų vèlavimas - tai pusantro karto daugiau nei Lietuvos įmonių vidurkis. Vidutiniškai 65 dienų atsiskaitymo terminas taip pat reiškia, kad tiekèjai nuolat kreditavo savo pirkejjus kredito dydžiu, lygiu $17 \%$ savo metinių pajamų.

6. Atsiskaitymų vèlavimas gali būti susijęs su nepakankamais kreditų vadybininkų pajėgumais užtikrinti skolų susigrąžinimą laiku: didesnis darbuotojų užimtumas gali lemti ilgesnę pirkèjų atsiskaitymų trukmę.

7. Tikètina, kad pailgejjus vèlavimo terminams išaugs ir beviltiškos skolos. Vadinasi, norint sumažinti nuostolius dèl beviltiškų skolų, visų pirma reikia sumažinti pirkejų atsiskaitymų vèlavimą.

8. Ilgesnius vèlavimus taip pat lemia ilgesni mokejjimo atidejimo terminai. Vadinasi, suteikdami pirkèjams mokèjimo atidejjimo terminus, o ypač norèdami juos pailginti, tiekèjai turi žinoti, kad viena suteikta diena realų atsiskaitymo terminą vidutiniškai pailgins daugiau nei pusantros dienos. Gauta išvada paneigia praktikoje paplitusi požiūrị, kad jei vèluoti linkusiems pirkejjams suteikiami ilgesni mokejjimo atidejjimo terminai, jie pradès vèluoti mažiau. Iš tiesų įmonès, spręsdamos vèlavimo problemą, turètų elgtis atvirkščiai ir trumpinti mokejjimo atidejimo terminus arba spręsti šią problemą kitais būdais, pvz., pasirinkdamos atitinkamas atsiskaitymų valdymo priemones.
9. Kredito rizikos valdymo priemonès galutinius atsiskaitymo terminus veikia dviem kanalais: pirma, tos i̇monès, kurios naudoja rizikos valdymo priemones, taiko trumpesnius mokejimo atidejimo terminus; antra, priemonių naudojimas sutrumpina ir vèlavimus.

10. Labiausiai vèlavimus sumažina kreditų draudimas, laidavimas ir faktoringas, t. y. tų priemonių, kurios i atsiskaitymų procesą įtraukia trečiąą šalị. Taip sukuriama „atsiskaitymų disciplina“, kai skolininkas žino, kad kreditorius, laiku nesulaukęs apmokèjimo, dèl atsiskaitymo galès kreiptis ị trečiąją šalị - draudiką, laiduotoją ar faktorių.

11. Nuostoliai dèl pirkèjų nemokumo tyrime dalyvavusiose ¿monèse $2006 \mathrm{~m}$. vidutiniškai sudare $0,68 \%$ pajamų. Šis rodiklis gerokai skyrèsi didesnèse ir mažesnèse įmonèse pastarųjų nenaudai.

12. Bet kokios kredito rizikos valdymo priemonès sumažina įmonių patiriamus nuostolius dèl pirkejų nemokumo, tačiau tos priemonès, kurias pačios įmonès laiko efektyviausiomis, iš tiesų nèra efektyviausios. Labiausiai nuostolius sumažina kreditų draudimas, faktoringas ir laidavimas, po kurių eina skolų išieškojimas. Užskaitos su išankstiniais mokejjimais gerokai atsilieka. Iš tiesų gauti rezultatai panašūs ị kredito rizikos valdymo priemonių itakos vèlavimų prevencijai rezultatus.

13. Vidiniai įmonių kredito limitai, vèlavimų prevencijoje, užèmę paskutinę vietą, mažinant nuostolingumą, patenka i pirmają.

14. Sudetingesnes ir brangesnes priemones, tokias kaip kreditų draudimas ar faktoringas, naudoja didesnès įmonès, o paprastesnes ir pigesnes, tokias kaip užskaitos ar išankstiniai mokejjimai, taiko mažesnès įmonès.

15. Daugiau nei pusei įmonių yra nepriimtina bet kokia su pardavimu susijusi kredito rizika. Apie trečdali ¿̇monių savo rizika pirkejams parduoda daugiau nei pusę prekių.

16. Didesnį rizikos lygị prisiimančios įmonès patiria didesnių nuostolių dèl pirkejų nemokumo. Didesnį rizikos lygi prisiimti linkusios mažesnès įmonès.

17. Naujai ịsteigtoms įmonèms būdinga didesne tyčinio nemokumo rizika, tad parduodant joms prekes reikia imtis ypatingų atsargumo priemonių.

18. Tyrimo metu paaiškejjo dvi įmonių grupès, kurių vieną apibrèžia didesnè pardavimo apimtis savo rizika ir paprastesnès bei pigesnès kredito rizikos valdymo priemonès bei ilgesni mokejjimo atidejimo terminai ir vèlavimas, o antrą - vengimas parduoti prekes savo rizika, brangesnès ir sudètingesnès priemonès ir atitinkamai trumpesni mokejjimo atidejimo terminai bei vèlavimas. Minètos pirmosios grupès įmonès 
vidutiniškai 2-3 kartus mažesnès nei antrosios ir kelis kartus nuostolingesnès, todèl turètų vengti pardavimo savo rizika, kartu su paprastesnemis rizikos valdymo priemonemis naudoti ir sudètingesnes bei trumpinti pirkejjų atsiskaitymų vẻlavimo trukmę.

\section{Literatūra}

Bardes, B. 2000. Délais de paiement et solde du crédit interentreprises de 1989 à 1998, Bulletin de la Banque de France 74: 63-79.

Boissay, F. 2004. Crédits interentreprises et délais de paiement: une théorie financière, Annales déconomie et de statistique 73: $101-118$.

Brennan, M. J.; Maksimovic, V.; Zechner, J. 1988. Vendor financing, Journal of Finance 43: 1127-1141.

Čekanavičius, V.; Murauskas, G. 2000. Statistika ir jos taikymai. Vilnius: TEV. 240 p.
Čekanavičius, V.; Murauskas, G. 2002. Statistika ir jos taikymai, II. Vilnius: TEV. 272 p.

Delannay, A. F.; Dietsch, M. 1999. Le crédit interentreprises joue un rôle d'amortisseur des tensions conjoncturelles. Revue d'Économie Financière 54.

Ferris, J. 1981. A transaction theory of trade credit use, Quarterly Journal of Economics 96: 243-270.

Gronskas, V. 1997. Prekines verslininkystès rizika. Kaunas: Technologija. $116 \mathrm{p}$.

Herzberg, F. I. 1964. The Motivation-Hygiene Concept and Problems of Manpower, Personnel Administration JanuaryFabruary: 486-497.

Intrum Justitia. 2006. Rizikos rodiklis - 2006 m. ruduo, Lietuva [interaktyvus] [žiūrèta 2009-02-14]. Prieiga per internetą: <http://www.intrum.lt/doc/Rizikos\%20rodiklis\%20\%20 2006\%20m\%20ruduo\%20Lietuva.pdf>.

Nadiri, M. 1969. The determinants of trade credit in the U. S. total manufacturing sector, Econometrica 37(3): 408-423.

Meilè JASIENĖ. Doctor of Social Sciences (Economics), Professor, Head of Department of Finance, Vilnius University. Author of about 100 publications. Research interests: risk management, financial markets, banking.

Antanas LAURINAVIČIUS. Master of Economics. Department of Finance, Vilnius University. Author of 1 publication. Research interests: risk management, financial markets. 